\title{
Air quality during the 2008 Beijing Olympics: secondary pollutants and regional impact
}

\author{
T. Wang ${ }^{1,2,3}$, W. Nie ${ }^{1,2}$, J. Gao ${ }^{3}$, L. K. Xue ${ }^{1,2}$, X. M. Gao ${ }^{1,2}$, X. F. Wang ${ }^{1,2}$, J. Qiu ${ }^{1}$, C. N. Poon ${ }^{1}$, S. Meinardi ${ }^{4}$, \\ D. Blake ${ }^{4}$, S. L. Wang ${ }^{3}$, A. J. Ding ${ }^{1}$, F. H. Chai ${ }^{3}$, Q. Z. Zhang ${ }^{2}$, and W. X. Wang ${ }^{2,3}$ \\ ${ }^{1}$ Department of Civil and Structural Engineering, The Hong Kong Polytechnic University, Hong Kong, China \\ ${ }^{2}$ Environment Research Institute, Shandong University, Jinan, China \\ ${ }^{3}$ Chinese Research Academy of Environmental Sciences, Beijing, China \\ ${ }^{4}$ Department of Chemistry, University of California at Irvine, Irvine, USA
}

Received: 9 April 2010 - Published in Atmos. Chem. Phys. Discuss.: 12 May 2010

Revised: 22 July 2010 - Accepted: 2 August 2010 - Published: 16 August 2010

\begin{abstract}
This paper presents the first results of the measurements of trace gases and aerosols at three surface sites in and outside Beijing before and during the 2008 Olympics. The official air pollution index near the Olympic Stadium and the data from our nearby site revealed an obvious association between air quality and meteorology and different responses of secondary and primary pollutants to the control measures. Ambient concentrations of vehicle-related nitrogen oxides $\left(\mathrm{NO}_{\mathrm{x}}\right)$ and volatile organic compounds (VOCs) at an urban site dropped by $25 \%$ and $20-45 \%$ in the first two weeks after full control was put in place, but the levels of ozone, sulfate and nitrate in $\mathrm{PM}_{2.5}$ increased by $16 \%, 64 \%$, $37 \%$, respectively, compared to the period prior to the full control; wind data and back trajectories indicated the contribution of regional pollution from the North China Plain. Air quality (for both primary and secondary pollutants) improved significantly during the Games, which were also associated with the changes in weather conditions (prolonged rainfall, decreased temperature, and more frequent air masses from clean regions). A comparison of the ozone data at three sites on eight ozone-pollution days, when the air masses were from the southeast-south-southwest sector, showed that regional pollution sources contributed $>34-88 \%$ to the peak ozone concentrations at the urban site in Beijing. Regional sources also contributed significantly to the CO concentrations in urban Beijing. Ozone production efficiencies at two sites were low ( $\sim 3 \mathrm{ppbv} / \mathrm{ppbv})$, indicating that ozone formation was being controlled by VOCs. Compared with data collected in 2005 at a downwind site, the concentrations of ozone, sulfur dioxide $\left(\mathrm{SO}_{2}\right)$, total sulfur $\left(\mathrm{SO}_{2}+\mathrm{PM}_{2.5}\right.$ sul-
\end{abstract}

Correspondence to: T. Wang (cetwang@polyu.edu.hk) fate), carbon monoxide $(\mathrm{CO})$, reactive aromatics (toluene and xylenes) sharply decreased (by 8-64\%) in 2008, but no significant changes were observed for the concentrations of $\mathrm{PM}_{2.5}$, fine sulfate, total odd reactive nitrogen $\left(\mathrm{NO}_{\mathrm{y}}\right)$, and longer lived alkanes and benzene. We suggest that these results indicate the success of the government's efforts in reducing emissions of $\mathrm{SO}_{2}, \mathrm{CO}$, and VOCs in Beijing, but increased regional emissions during 2005-2008. More stringent control of regional emissions will be needed for significant reductions of ozone and fine particulate pollution in Beijing.

\section{Introduction}

The air quality in Beijing has been of great concern to both the Chinese government and researchers, especially after the city won the bid to host the 29th Summer Olympic Games. To significantly improve the city's air quality during the Games (8-24 August 2008), in addition to the long-term control measures (UNEP, 2009), the Chinese government took drastic actions to reduce the emissions of air pollutants from industry, road traffic, and construction sites (UNEP, 2009; Wang et al., 2009a, 2010b). From 1 July, some 300000 heavily polluting vehicles (the so called yellow-label vehicles) were banned from driving in the Beijing Municipality, which covers an area of $16808 \mathrm{~km}^{2}$, and starting from 20 July, half of the city's 3.5 million vehicles were taken off the roads through the alternative day-driving scheme. In addition, all construction activities were halted, power plants were asked to use cleaner fuels, and some polluting factories were ordered to reduce their activity. Additional control was implemented after the start of the Games in order to further

Published by Copernicus Publications on behalf of the European Geosciences Union. 
reduce the emissions from vehicles and petrol-filling stations (Wang et al., 2009a). In addition to the strict controls on air pollution sources in Beijing, neighboring provinces also reduced their industrial output. A preliminary assessment suggests that these emission-reduction measures reduced the emissions of $\mathrm{SO}_{2}, \mathrm{NO}_{\mathrm{x}}, \mathrm{CO}$, VOCs, and $\mathrm{PM}_{10}$ by $14 \%, 38 \%$, $47 \%, 30 \%$, and $20 \%$ in the Beijing area, respectively (UNEP, 2009). Much larger reductions of $\mathrm{SO}_{2}(41 \%), \mathrm{NO}_{\mathrm{x}}(47 \%)$, VOCs $(57 \%)$, and $\mathrm{PM}_{10}(55 \%)$ are suggested in a more recent study (Wang et al., 2010b).

The large reductions in pollution emissions in the summer of 2008 in Beijing represents a human-perturbation experiment of unprecedented scale, and provides a rare opportunity to study the impact of pollution emissions on the air quality and atmospheric chemistry of Beijing and the surrounding regions. From an air-quality management point of view, it is of critical importance to know how the anticipated large reduction in emissions improved the city's air quality. During the summer of 2008, we measured trace gases and aerosols at three sites in and around Beijing before, during, and after the Games. Here, we report the first results from the analysis of this dataset, which provide new insights into the role of meteorology, the response of secondary pollutants to the pollution control, and the contribution of regional pollution to the air quality in Beijing.

A number of papers have been published on the results of surface and satellite measurements during the Beijing Olympics, all indicating sharp decreases in the concentrations of the measured pollutants in Beijing during the period of the Olympics. On-road measurements reported significant (12-70\%) decreases in the ambient concentrations of $\mathrm{CO}$, $\mathrm{NO}_{\mathrm{x}}, \mathrm{SO}_{2}$, black carbon (BC), benzene, toluene, ethylbenzene, and xylenes (BTEX), and $\mathrm{PM}_{1}$ during the Olympics (Wang et al., 2009a). Atmospheric measurements at other urban sites showed a decrease in the concentration of 35-43\% for fine and coarse particulate matter (Wang et al., 2009b), $74 \%$ for BC (Wang et al., 2009c), 47-64\% for BTEX (Liu et al., 2009), and 35\% for total non-methane hydrocarbons (Wang et al., 2010a). These results were based on a comparison of the data obtained during the Olympics with those from non-Olympic periods (before and/or after the Olympics and Para-Olympics). The concentrations of $\mathrm{O}_{3}, \mathrm{CO}, \mathrm{SO}_{2}$, and $\mathrm{NO}_{\mathrm{y}}$ in plumes from urban Beijing transported to a rural site deceased by $21-61 \%$ in August 2008 compared to the same month in 2007 (Wang et al., 2009d). Analyses of satellite data from GOME-2, OMI, and MODIS, by comparing the results obtained during August 2008 with those in the same period in previous years, have shown a decrease of $43-59 \%$ in nitrogen dioxide $\left(\mathrm{NO}_{2}\right)$ column over Beijing (Mijling et al., 2009; Witte et al., 2009), $13 \%$ in boundary-layer $\mathrm{SO}_{2}, 12 \%$ in $\mathrm{CO}$ at the $700 \mathrm{hPa}-$ level over a large region encompassing Beijing and its southern neighboring provinces (Witte et al., 2009), and $11 \%$ in aerosol optical thickness over Beijing (Cermak and Kutti, 2009).
With the aid of a chemical transport model or a statistical model, some studies have attempted to examine the relative role of meteorology and emission reduction in the improvement of the air qualities during the Olympics. Wang et al. (2009c) attributed 55\% of the ozone decrease at a rural site during the Olympics from the same period in the previous year to the change in meteorology during the two years. Wang et al. (2009a) suggested a more dominant role of meteorological effects than the emission reductions in the variation in their observed particulate matter at an urban site. Cermak and Kutti (2009) also suggested a more important role of the meteorology in explaining the decrease in aerosol optical thickness. Mijling et al. (2009) attributed the $60 \%$ reduction in tropospheric $\mathrm{NO}_{2}$ to the emission control.

Most of these published studies so far have focused on primary pollutants, and there are few results on the levels and variation of secondary pollutants and on the extent of regional contribution during the drastic emission control in Beijing. In addition, little attention has been given to the paradoxical response of secondary pollutants during the first two weeks after the full traffic control. The present study attempts to examine these important topics. We first show the relationship between weather and the general air quality in Beijing as indicated by the official air pollution index and our own measurements; we then estimate the regional contribution to ozone pollution on eight days when Beijing was influenced by air masses from the North China Plain in the south; we also examine the ozone production efficiencies, and lastly we compare the data collected at a downwind site in 2005 and 2008 to gain insight into the changes in the composition of urban and regional plumes, and discuss the changes in Beijing and regional emissions during the past several years.

\section{Methodology}

\subsection{Measurement sites}

Field studies were conducted at three sites in and outside the Beijing urban area that lie roughly on a south-north axis. The three sites are shown in Fig. 1 and are described in the following.

Xicicun (XCC) is situated near the border between Beijing and the Hebei province $\left(39^{\circ} 28^{\prime} \mathrm{N}, 116^{\circ} 7^{\prime} \mathrm{E}\right)$, and is $53 \mathrm{~km}$ southwest of the center of Beijing (Tiananmen). When the winds come from the south or southwest, this site is upwind of the Beijing urban area. The site is located in farmland with few nearby sources of pollution. The ozone and $\mathrm{CO}$ data from this site are reported in this paper. The measurements were conducted between 20 July and 25 August.

The Chinese Research Academy of Environmental Sciences (CRAES) is located $4 \mathrm{~km}$ north of the 5 th ring road, $15 \mathrm{~km}$ from the city center, and $5.8 \mathrm{~km}$ from the National Olympic Stadium (the "Bird's Nest"). This site is 

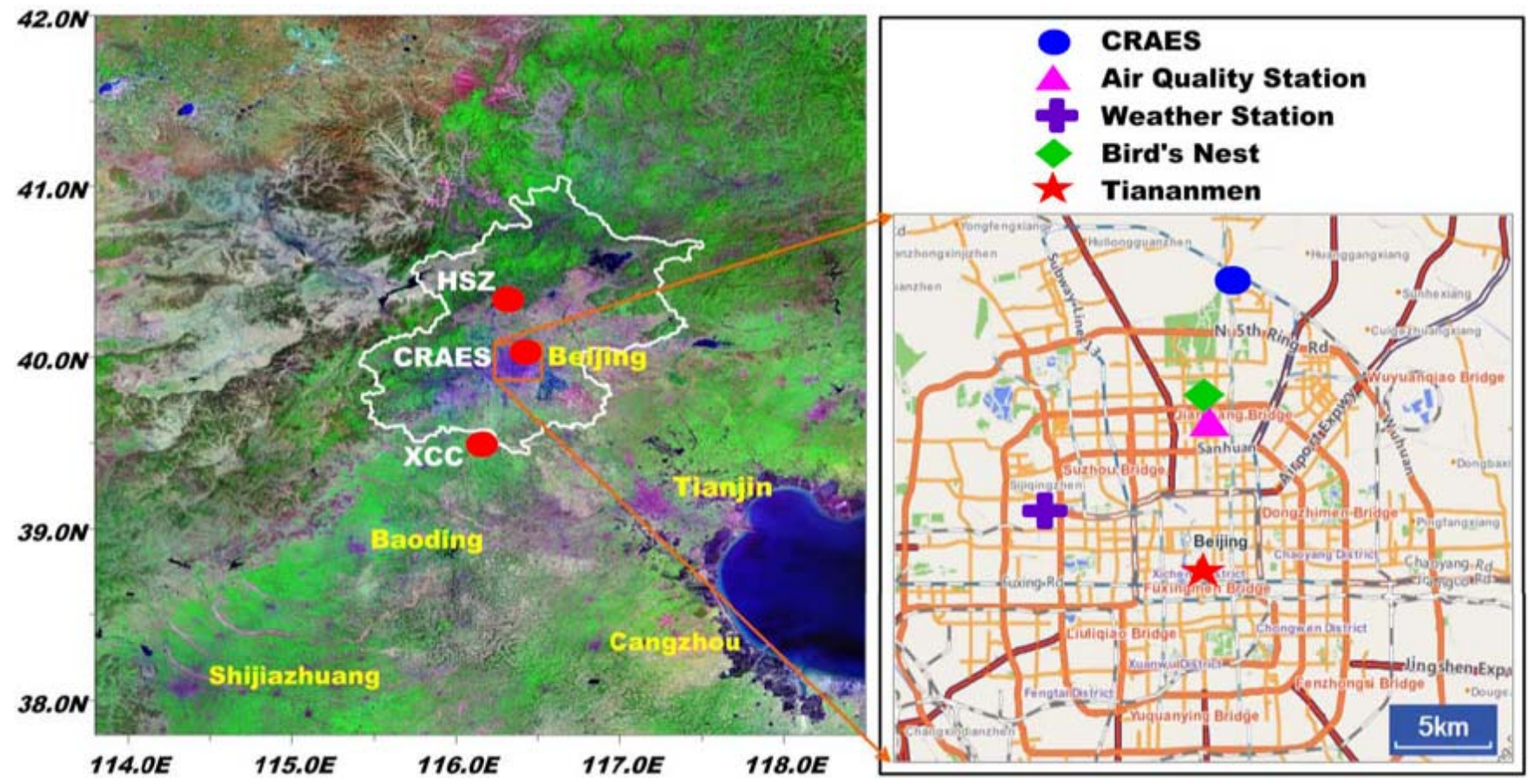

Fig. 1. Map showing the three measurement sites (XCC, CRAES, HSZ), the Beijing Municipality (the area within the white line), and the surrounding regions. Also shown are the location of the "Bird's Nest" National Olympic Stadium, a Beijing Municipal Environmental Protection Bureau's air quality station and a Beijing Municipal Meteorological Bureau's weather station whose data are used in this study.

immediately downwind of the maximum emissions from urban Beijing, and is the most heavily instrumented of the three sites. The site is located on the rooftop of a three-floor building in the Academy. Data on ozone, $\mathrm{CO}, \mathrm{NO}_{\mathrm{x}}, \mathrm{NO}_{\mathrm{y}}$, VOCs from canisters, real-time $\mathrm{PM}_{2.5}$ sulfate and nitrate taken between 10 July and 25 August are analyzed in this paper.

Heishanzhai (HSZ) is a rural mountainous area $\left(40^{\circ} 22^{\prime} \mathrm{N}\right.$, $116^{\circ} 18^{\prime} \mathrm{E}, 280 \mathrm{~m}$ above sea level), approximately $50 \mathrm{~km}$ north of the center of Beijing. This site was used in our previous study in the summer of 2005, when high concentrations of ozone and secondary aerosol were observed (Wang et al., 2006; Pathak et al., 2009). In 2008, a different building was used for the measurements due to renovation work in the previous facility. This paper compares the $\mathrm{O}_{3}, \mathrm{CO}, \mathrm{SO}_{2}, \mathrm{NO}_{\mathrm{y}}$, 24-h $\mathrm{PM}_{2.5}$ mass, sulfate, nitrate, and NMHCs data during 10 July-August 252008 with the corresponding data from July of 2005.

\subsection{Instrumentation}

A brief description of the methods used to measure the gases and aerosols is given in the following. The reader is referred to relevant previous publications for further details. The limits of detections of the techniques are all sufficient to accurately measure the relatively high concentrations of gases and aerosols at the study sites.

Trace gases: $\mathrm{O}_{3}$ was measured with a UV photometric analyzer (TEI model 49i), CO with a non-dispersive infrared analyzer (API model 300EU or API model 300E), and $\mathrm{SO}_{2}$ with a pulsed UV fluorescence analyzer (TEI model 43C). Nitric oxide (NO) and $\mathrm{NO}_{\mathrm{y}}$ were measured with a commercial chemiluminescence analyzer fitted with an externally placed molybdenum oxide (MoO) catalytic converter (Wang et al., 2001). $\mathrm{NO}_{\mathrm{y}}$ is defined as the sum of $\mathrm{NO}, \mathrm{NO}_{2}, \mathrm{HONO}$, $\mathrm{HO}_{2} \mathrm{NO}_{2}, \mathrm{NO}_{3}, \mathrm{PAN}, \mathrm{HNO}_{3}, \mathrm{~N}_{2} \mathrm{O}_{5}$, aerosol nitrate, and other organic nitrates etc, including nitrate in $\mathrm{PM}_{2.5}$. A photolytic converter (Blue Light converter, Meteorologie Consult Gubh) coupled to a commercial NO analyzer was used to measure $\mathrm{NO}_{2}$. The methods used to calibrate these instruments were the same as those reported by Wang et al. (2001). The $\mathrm{NO}_{2}$ conversion efficiencies were determined by the gasphase titration method, and an average efficiency of $35 \%$ was obtained.

Methane, NMHC, and halocarbon concentrations were determined by collecting whole-air samples in evacuated $2 \mathrm{~L}$ electro-polished stainless steel canisters each equipped with a bellows valve. Between one and seven samples were collected each day, with more samples being collected on episode days. The sampling duration was $2 \mathrm{~min}$. The canisters were shipped to the University of California at Irvine for chemical analysis using gas chromatography with flame ionization detection, electron capture detection, and mass spectrometer detection (Colman et al., 2001).

Aerosols: At the HSZ site, 24-h $\mathrm{PM}_{2.5}$ samples were collected using a Thermo Andersen Chemical Speciation 


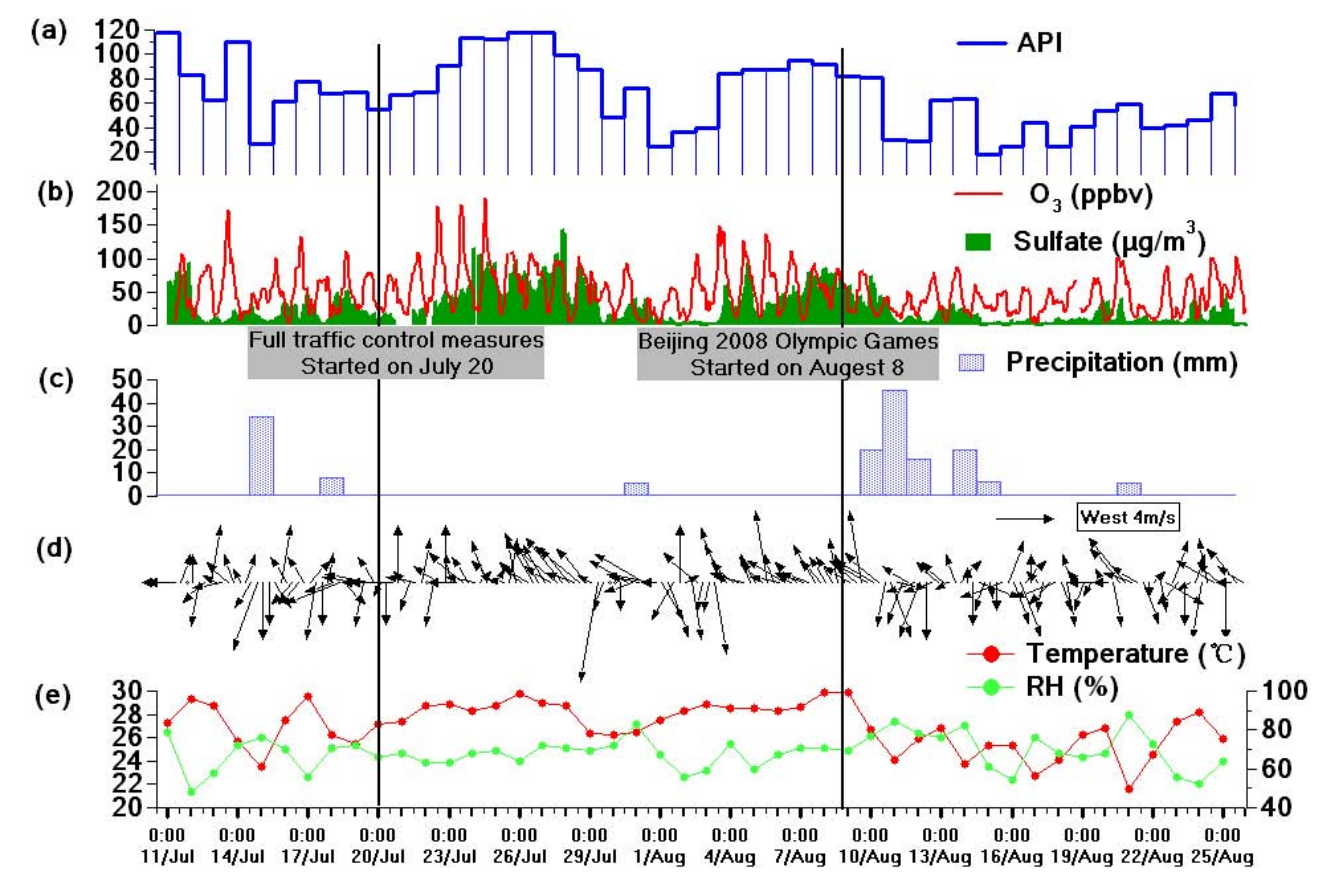

Fig. 2. Time series of (a) Air Pollution Index at a Beijing Municipal Environmental Protection Bureau's air-quality monitoring station at the Chaoyang National Olympics Sports Center, (b) hourly concentration of ozone and $\mathrm{PM}_{2.5}$ sulfate measured at CRAES, (c) daily precipitation amount, (d) four-hourly wind vectors, (e) daily mean temperature and relative humidity. The meteorological data were obtained from a Beijing Municipal Meteorological Bureau's weather station (see Fig. 1 for its location).

Monitor (RAAS2.5-400, Thermo Electron Corporation) with Teflon filters $\left(\mathrm{Teflo}^{\mathrm{TM}}, 2 \mu \mathrm{m}\right.$ pore size and $47 \mathrm{~mm}$ diameter, Pall Inc.) at a flow rate of 16.7 LPM (Wu and Wang, 2007). The $\mathrm{PM}_{2.5}$ mass was determined using the standard gravimetric method, and the water soluble ions $\mathrm{SO}_{4}^{2-}, \mathrm{NO}_{3}^{-}$, $\mathrm{F}^{-}, \mathrm{Cl}^{-}, \mathrm{NO}_{2}^{-}, \mathrm{NH}_{4}^{+}, \mathrm{K}^{+}, \mathrm{Na}^{+}, \mathrm{Mg}^{2+}$, and $\mathrm{Ca}^{2+}$ were analyzed using a Dionex ion chromatography 90 (Wu and Wang, 2007). At CRAES, real-time $\mathrm{PM}_{2.5}$ ions were measured using an ambient ion monitor (URG 9000B, URG Corporation) (Wu and Wang, 2007). Another instrument (same model) was used in 2008, however, the negative artifact reported in the previous study was not observed.

\subsection{Air pollution index, meteorological data, and back trajectories}

In order to show the air quality at the main Olympic complex and its relationship with the secondary pollutants measured at our nearby CRAES, we obtained official Air Pollution Index (API) data (http://www.bjepb.gov.cn) at the Beijing Municipal Environmental Protection Bureau (BJEPB)'s air-quality monitoring station at Chaoyang Olympics Sports Center, located about $2 \mathrm{~km}$ south and southeast of the "Bird's Nest" (Fig. 1). The API is calculated based on the highest index of 24-h average concentrations of $\mathrm{PM}_{10}, \mathrm{SO}_{2}$, and $\mathrm{NO}_{2}$ from noon of the present day to noon of the pervious day. An API of 0-50, 51-100, and 101-200 is classified as "excel- lent", "good", and "slightly polluted" condition, respectively (UNEP, 2009).

To help interpret the chemical data, we used surface meteorological data on precipitation, temperature, relative humidity, and wind speed and direction obtained from the Beijing Municipal Meteorological Bureau (BJMB) weather station located to the west of the city center (Fig. 1). The wind data were collected four times a day $(02: 00,08: 00,14: 00$, and 20:00, local time), and the other data were daily averages. These data were obtained from Global Telecommunication Systems. In addition to surface winds, 48-h backward trajectories were calculated to identify the origin and transport pathway of large-scale air masses. The trajectories were calculated for four times a day (02:00, 08:00, 14:00, and 20:00, local time) using the NOAA ARL HYSPLIT model with GDAS (Global Data Assimilation System) data (http://ready.arl.noaa.gov/HYSPLIT.php), with the endpoint at the CRAES, and at an altitude of $100 \mathrm{~m}$ above ground level.

\section{Results and discussion}

\subsection{Overall air quality and relation to weather conditions}

Figure 2 shows the daily API, the hourly concentrations of ozone and sulfate at CRAES, and several meteorological 


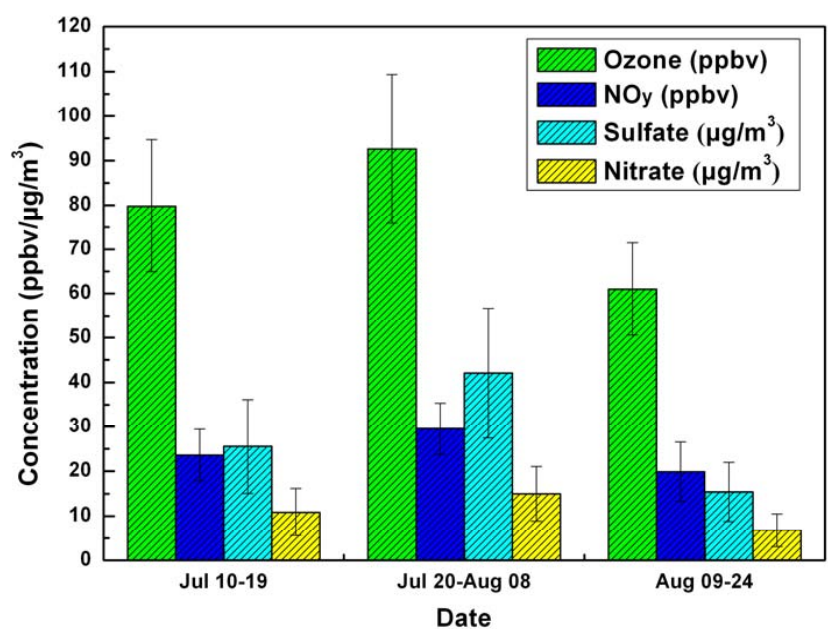

Fig. 3. Average concentration of secondary pollutants at CRAES: ozone (for the 11:00-18:00 period), $\mathrm{NO}_{\mathrm{y}}, \mathrm{PM}_{2.5}$ sulfate and nitrate, during the three periods, namely before the full control (1019 July), after the full control (20 July-8 August), and during the Olympics (9-24 August). Vertical bars are half standard deviations.

parameters from BJMB from July 11 to August 25. During the observation period, $\mathrm{PM}_{10}$ was the dominant pollutant of the three reported pollutants $\left(\mathrm{PM}_{10}, \mathrm{SO}_{2}\right.$, and $\left.\mathrm{NO}_{2}\right)$ at the BJEPB site. Thus the officially reported air quality represented levels of coarse particulate matter. An API of 0-50, $51-100$, and 101-200 corresponds to $0-50,52-150,152-$ $350 \mu \mathrm{g} / \mathrm{m}^{3}$ of $\mathrm{PM}_{10}$, respectively (UNEP, 2009). However, because the computation of API does not include ozone, the API does not adequately reflect the situation of photochemical pollution. Thus the combined API and the secondary pollutants at our site shown in Fig. 2 better illustrate the variations in air quality (for both primary and secondary pollutants) in the Olympics complex and the adjacent areas.

The observation period can be divided into three parts: (1) before the full-scale control (11-19 July), (2) after the full-scale control but before the Olympics (20 July to $8 \mathrm{Au}$ gust), and (3) during the Olympics (9-24 August). Moderately high API (60-120) (and ozone and sulfate concentrations) was recorded in the first period. After the full traffic control came into effect, two multi-day pollution episodes occurred: one between 23 and 29 July, and one started three day before the Olympic openings and lasted for five days (49 August). The highest readings of API, ozone, and sulfate occurred during this period: nine days had a maximum 1$\mathrm{h}$ ozone exceeding China's ambient air quality standard of $100 \mathrm{ppbv}$, with the highest value of $190 \mathrm{ppbv}$ being recorded on 24 July; very high concentrations of sulfate (hourly values of $80-140 \mu \mathrm{g} / \mathrm{m}^{3}$ ) were also observed. Good air quality was recorded on most days during the Games, as indicated by the lowest API values and the concentrations of secondary pollutants (see Fig. 2).
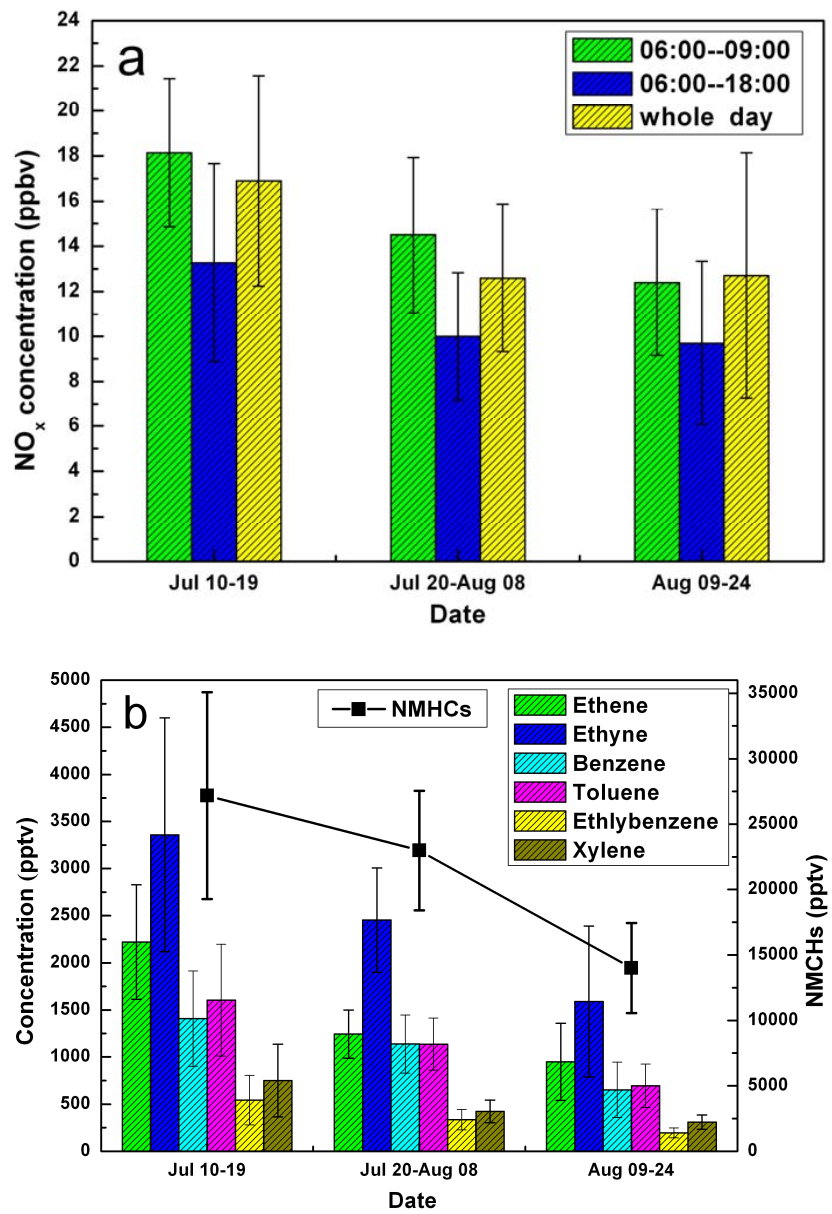

Fig. 4. Mean concentration of vehicle-related primary pollutants during the three periods at CRAES (a) $\mathrm{NO}_{\mathrm{x}}$ during rush hours, daytime and whole day and (b) individual and total $\mathrm{C}_{2}-\mathrm{C}_{8}$ NMHCs. Vertical bars are half standard deviations. The number of VOC samples is $6,14,14$ for period 1,2 , and 3 , respectively.

Figure 2 reveals that while the API captured the day-today variation of fine sulfate, which can be explained by the fact that sulfate is a part of $\mathrm{PM}_{10}$, it did not adequately reflect the concentrations and variation of ozone: the three highest ozone days on 22-24 July were not indicated by the API, illustrating the deficiency of the current API in representing photochemical pollution.

Figure 3 gives the average concentrations and half of the standard deviations in the three periods for ozone (11:00 18:00, local time), sulfate, nitrate, and $\mathrm{NO}_{\mathrm{y}}$ at CRAES. They represent secondary gases and aerosols. In aged air masses $\mathrm{NO}_{\mathrm{y}}$ contains a large fraction of oxidation products of $\mathrm{NO}_{\mathrm{x}}$, such as in period 2 during which $\mathrm{NO}_{\mathrm{x}}$ was only $\sim 40 \%$ of $\mathrm{NO}_{\mathrm{y}}$ (see Figs. 3 and 4).

The results shown in Figs. 2 and 3 are striking. The control measures were expected to reduce significantly emissions from vehicles, power generation, and other activities (e.g, Wang et al., 2010b). Indeed, $\mathrm{NO}_{\mathrm{x}}$ measured at CRAES 

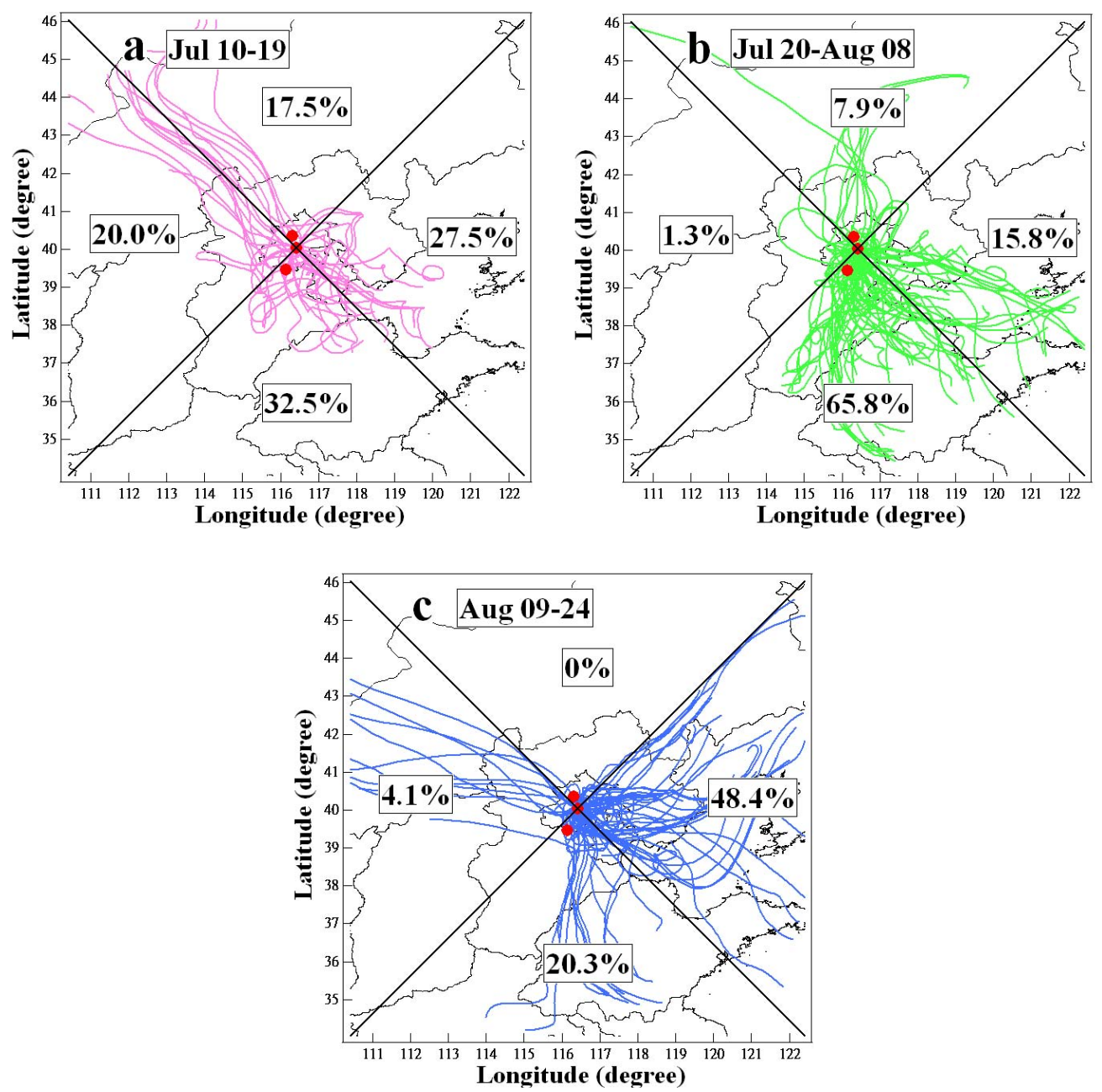

Fig. 5. Forty-eight hour backward trajectories during (a) 10-19 July (b) 20 July-8 August and (c) 9-24 August. Numbers are the percentage contributions from each of the four sectors. The percentage of non-defined (i.e. looping) trajectories is $2.5 \%, 9.2 \%$ and $27.2 \%$ for period 1 , 2 and 3, respectively. The red points are the locations of the XCC, CRAES, and HSZ sites.

decreased by $20 \%$ and $25 \%$ in the morning (06:00-09:00, local time) and for the whole day, respectively (Fig. 4). Twotailed $t$ tests show that these differences are statistically significant at $99 \%$ confidence level (i.e., $P<0.01$ ). The canister samples collected in the afternoon also showed $20-45 \%$ decreases for ethene, ethyne, benzene, toluene, ethylbenzene and xylenes which are typical compounds from vehicular emissions. However, the levels of statistical significance for the changes in these VOCs are lower $(P>0.05$, that is, below 95\% confidence level) than the continuously measured constituents due in part to the fewer samples of VOCs. The drop in $\mathrm{NO}_{\mathrm{x}}$ and the apparent decreases in the VOCs at CRAES are consistent with other on-road and ambient measurements of $\mathrm{NO}_{\mathrm{x}}$ and VOCs (Wang et al., 2009a, 2010a), indicating the effectiveness of the control measures on reducing vehicle emissions. The decreasing levels of toluene, ethylbenzene, and xylene were also due to the control of the usages of paints and solvents and of evaporation from petrol stations.
In contrast to the decreasing levels of $\mathrm{NO}_{\mathrm{x}}$ and the VOCs, the average concentration of ozone, $\mathrm{NO}_{\mathrm{y}}, \mathrm{PM}_{2.5}$ sulfate and nitrate at CRAES increased by $16 \%(P<0.05), 25 \%$ $(P<0.01), 64 \%(P<0.01)$, and 37\% $(P<0.01)$, respectively after the full control (see Fig. 3). This result reveals that emission control implemented after July 20 was not sufficient to eliminate the occurrences of high concentrations of ozone and particulate under adverse meteorological conditions.

Was the observed increase in ozone concentrations after the full control a result of decreased titration by $\mathrm{NO}_{\mathrm{x}}$ ? According to Fig. 4, $\mathrm{NO}_{\mathrm{x}}$ concentrations at CRAES decreased by $3-4$ ppbv in period 2 , which was much smaller than the increase of 13 ppbv in daytime $\mathrm{O}_{3}$ concentration (see Fig. 3), indicating that the reduced titration by local NO was not the dominant cause of the $\mathrm{O}_{3}$ increase in period 2. As to ozone production, both ambient data (Fig. 4 of the present study) and emission inventory (Wang et al., 2010b) indicate a larger reduction in the emission of reactive VOCs than in $\mathrm{NO}_{\mathrm{x}}$ after 

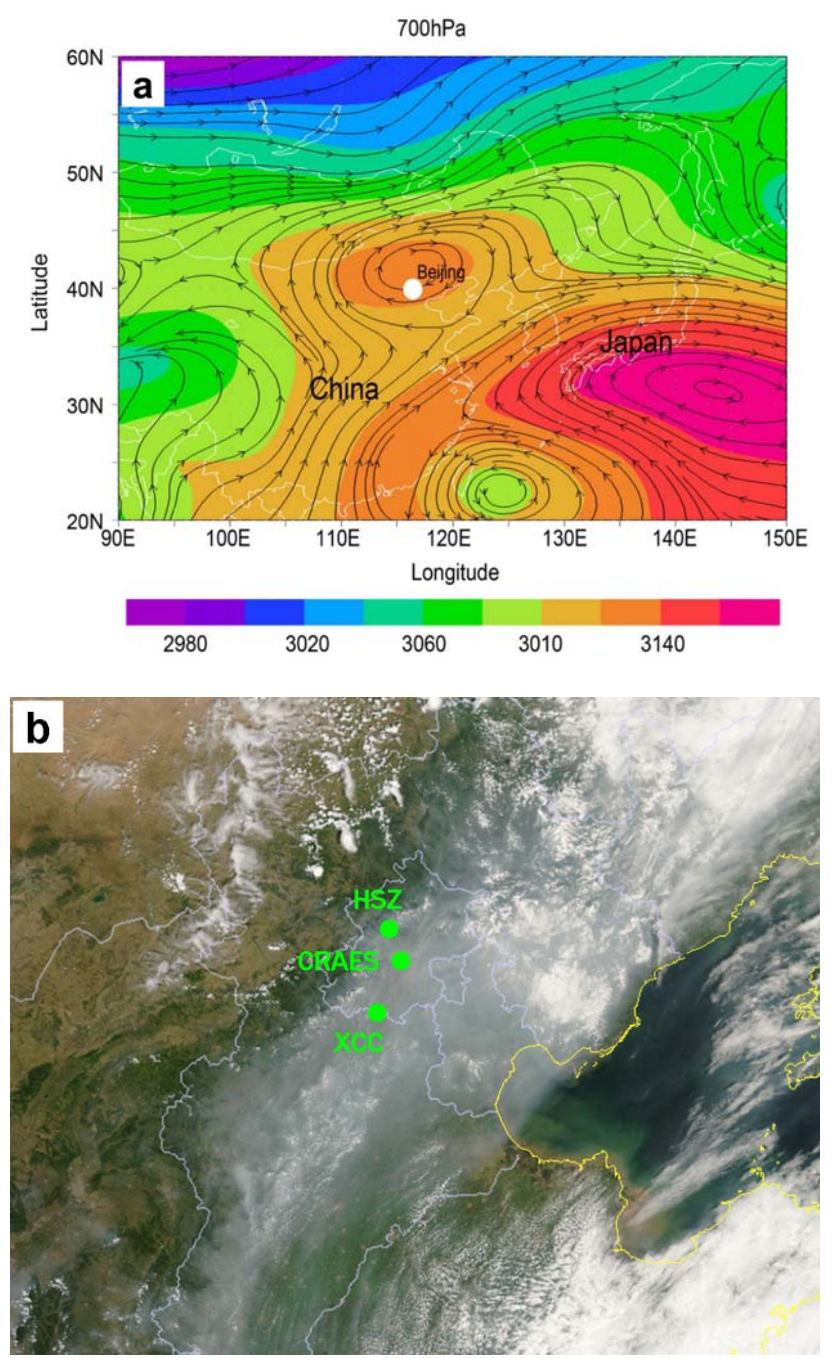

Fig. 6. (a) Mean wind and geopotential height for a multi-day pollution episode on 22-28 July 2008 (b) MODIS true-color imagery on 24 July.

20 July. The control measures are expected to reduce the production of ozone from Beijing, regardless whether the ozone formation is controlled by VOCs, $\mathrm{NO}_{\mathrm{x}}$, or both. Therefore, the observed increasing (both mean and peak) ozone concentrations must be mainly due to other reason(s). A $64 \%$ increase in the mean sulfate concentration in period 2 was also in sharp contrast of an anticipated $40 \%$ decrease in $\mathrm{SO}_{2}$ emission from Beijing (c.f. Fig. 1a in Wang et al., 2010b). We show later in this section that regional pollution played a vital role in the air quality during 20 July-8 August.

The concurrent measurements of ozone and sulfate (Fig. 2) reveal another interesting phenomenon: the highest ozone concentrations preceded those of sulfate, indicating that somewhat different meteorological conditions promoted the formation of ozone and particulate sulfate. The high levels of ozone (and by inference other oxidants) may have accel- erated the oxidation of $\mathrm{SO}_{2}$ to form sulfate. The hazy conditions in the later phase of the episode may have suppressed the production of ozone by reducing the rate of photolysis reactions and via uptake of radicals and $\mathrm{NO}_{\mathrm{x}}$ on moist aerosols.

Meteorological data shown in Fig. 2 (ambient temperature, relative humidity, wind direction and speed, and daily rainfall readings) reveal obvious impact of weather on the air quality. The increasing concentrations of secondary pollutants after the full control was associated with a lack of rainfall and the prevalence of southerly winds; the good air quality from August 10 through to the end of the Games can be partly explained by the persistent rain during 10-16 August, which also lowered the temperatures by a few degrees. Back trajectories during the three periods are shown in Fig. 5. They indicate much more frequent transport of regional pollution from the SE-S-SW directions (66\%) during period 2 compared to the period before the full control $(33 \%)$ and the period of Olympics $(20 \%)$. It is known that there are a large number of pollution sources in the North China Plain to the south of Beijing. It is worth noting that the two episodes on July 23-29 and August 4-9 are typical summertime pollution cases, during which Beijing and the surrounding regions are influenced by a weak high-pressure system over the Hebei Province (Fig. 6a) that gave rise to hot and humid "sauna" weather. Under such conditions, widespread pollution occurs not only in Beijing but also over a large part of the North China Plain, as illustrated by the true-color image from MODIS for July 24 (Fig. 6b) (http://rapidfire.sci.gsfc. nasa.gov/subsets/?subset=FAS_China4.2008206.aqua. $1 \mathrm{~km}$ ).

In sum, the above results clearly show the effects of weather and regional sources on the air quality during the study period. Additional modeling studies are needed to resolve the complex interplay between the changing emissions and meteorological conditions and to quantify local and regional contributions.

\subsection{Regional contribution to ozone pollution in Beijing}

It has been recognized that neighboring Tianjin, Hebei, Shanxi, and Shandong can have an important impact on Beijing's air quality (An et al., 2007; Chen et al., 2007; Streets et al., 2007; Jia et al., 2008; Wang et al., 2008; Lin et al., 2009). Model calculation by Streets et al. (2007) suggested that 35$60 \%$ of the simulated ozone at the Olympic Stadium site under July 2001 polluted conditions could be attributed to sources outside Beijing. Lin et al. (2009) observed elevated concentrations of $\mathrm{O}_{3}, \mathrm{CO}, \mathrm{SO}_{2}$, and $\mathrm{NO}_{\mathrm{x}}$ during summer at a polluted rural site (Gucheng), which is $110 \mathrm{~km}$ southwest of Beijing, and found that $80 \%$ of the northward trajectories from the site passed Beijing in August. Guo et al. (2010) compared particulate data at a site south of Beijing and another site inside Beijing in the summer of 2006 and showed that almost $90 \%$ fine sulfates were from regional contributions. 

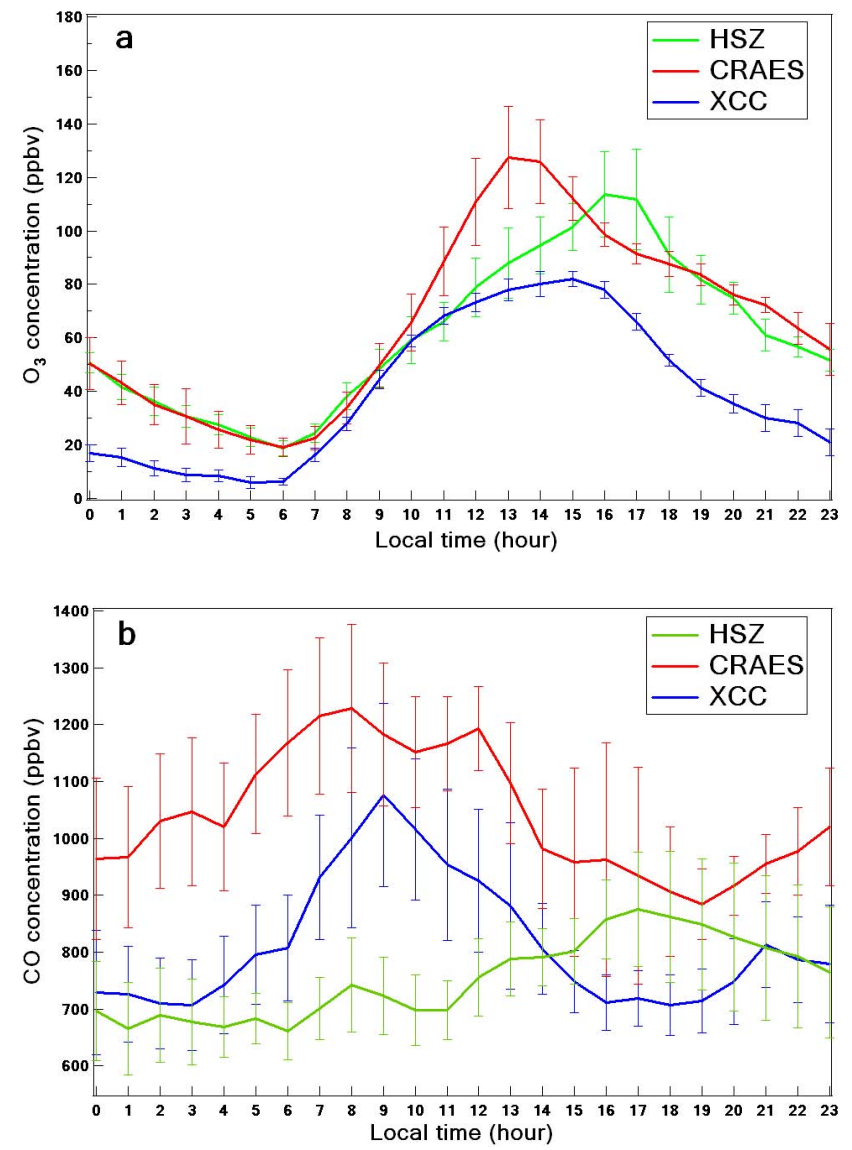

Fig. 7. Average diurnal variation of (a) ozone and (b) CO at three sites for eight ozone-pollution days when southerly winds prevailed. Vertical bars are half standard deviations.

The concurrent observations of ozone at three sites in the present study allow a direct examination of the regional contribution to ozone pollution in Beijing and the evaluation of Beijing plumes to downwind areas. To examine the regional contribution from the south, we selected days with ozone pollution (defined as 1 -h ozone $\geq 100 \mathrm{ppbv}$ at either of the three sites) that met the following criteria: (1) a day on which all four backward trajectories were from the SE-S-SW sector and (2) surface winds were also from that sector throughout the day, that is, no reversal in wind direction. Eight days were identified, including 23-28 July and 4-6 August. (There were no ozone data in the afternoon at CRAES on 25 July, and thus this day was not included.)

Figure 7 a shows the average diurnal variation in ozone for the eight days at the three sites. By taking the difference between the maximum 1-h ozone concentration at the urban site and the ozone value at the same time at the upwind site, we can estimate the contribution from regional sources in the south in each case. The result shows the regional sources contributed $34-88 \%$ to the peak ozone at the urban site for the eight cases, with an average contribution of $62 \%$. It should be pointed out that these estimates are likely to be the lower limits of the regional contribution as additional ozone was produced as the air was transported from the upwind site and the urban site. Figure $7 \mathrm{~b}$ shows the mean diurnal plot for $\mathrm{CO}$ for the eight cases. The mean $\mathrm{CO}$ concentration at the upwind site was $69-91 \%$ of that at the urban site during morning and early afternoon, indicating strong regional contribution of CO (and possibly other ozone precursors). Emissions from cities, townships, villages, and agriculture fields in the North China Plain are believed to the sources.

Figure 7 shows that the ozone (and $\mathrm{CO}$ ) peak at the downwind site lagged behind that at the urban site in time, which indicates that regional and Beijing plumes were transported to the mountain site in the afternoon (Wang et al., 2006). The lower ozone peak values at the downwind site (except in two cases) indicate that (1) ozone formation had reached maximum strength before reaching the site and/or (2) the ozonerich plumes had been subjected to dilution during transport.

\subsection{Ozone production efficiencies in urban and down- wind areas}

Ozone is formed by the oxidation of VOCs in the presence of $\mathrm{NO}_{\mathrm{x}}$ and sunlight. Ozone is produced when $\mathrm{NO}_{\mathrm{x}}$ is oxidized to various forms of $\mathrm{NO}_{\mathrm{y}}$, such as nitric acid, aerosol nitrate, and PAN. The ozone production efficiency (OPE), defined as the number of $\mathrm{O}_{3}$ molecules produced for each $\mathrm{NO}_{\mathrm{x}}$ molecule oxidized, can be expressed by the observed $\mathrm{O}_{3}$ versus $\mathrm{NO}_{\mathrm{z}}\left(\mathrm{NO}_{\mathrm{z}}=\mathrm{NO}_{\mathrm{y}}-\mathrm{NO}_{\mathrm{x}}\right)$ (Trainer et al., 1993). In polluted environments, $\mathrm{O}_{3}+\mathrm{NO}_{2}$ versus $\mathrm{NO}_{\mathrm{z}}$ is often used to consider the effect of NO titration. Figure 8 shows the scatter plots at CRAES and HSZ for the hourly data collected in the afternoon (12:00-17:00, local time), which is when the maximum photochemistry occurs. $\left(\mathrm{NO}_{\mathrm{z}}\right.$ was not measured at the southern site.) Expanding the period to include the data from 10:00 in the morning showed very similar regression slopes with a smaller correlation coefficient (figure not shown).

Several interesting features were observed. First, the upper concentrations of ozone and $\mathrm{NO}_{\mathrm{Z}}$ are comparable at the two sites despite the more remote location of HSZ, suggesting that both sites experienced serious photochemical pollution. Second, a non-linear ozone- $\mathrm{NO}_{\mathrm{z}}$ relationship was observed, with the slope $\left(\left[\mathrm{O}_{3}+\mathrm{NO}_{2}\right] /\left[\mathrm{NO}_{\mathrm{z}}\right]\right)$ at $\mathrm{NO}_{\mathrm{z}}<10 \mathrm{ppbv}$ being larger $(6.5 \pm 0.54$ and $7.7 \pm 0.78 \mathrm{ppbv} / \mathrm{ppbv})$ than that at $\mathrm{NO}_{\mathrm{z}} \geq 10 \mathrm{ppbv}(2.7 \pm 0.49$ and $4.0 \pm 0.80 \mathrm{ppbv} / \mathrm{ppbv})$. This can be explained by regional/diluted urban air being $\mathrm{NO}_{\mathrm{x}}{ }^{-}$ limited and the VOC-limited conditions of the polluted air masses. (Note that the slopes were determined with the reduced major axis (RMA) method to take into account measurement uncertainties in both the $x$ and $y$ variables, Hirsch and Gilroy, 1984.) We also separately examined the scatter plots for the periods before and after the full traffic control, but did not find a significant difference in the respective slopes. 


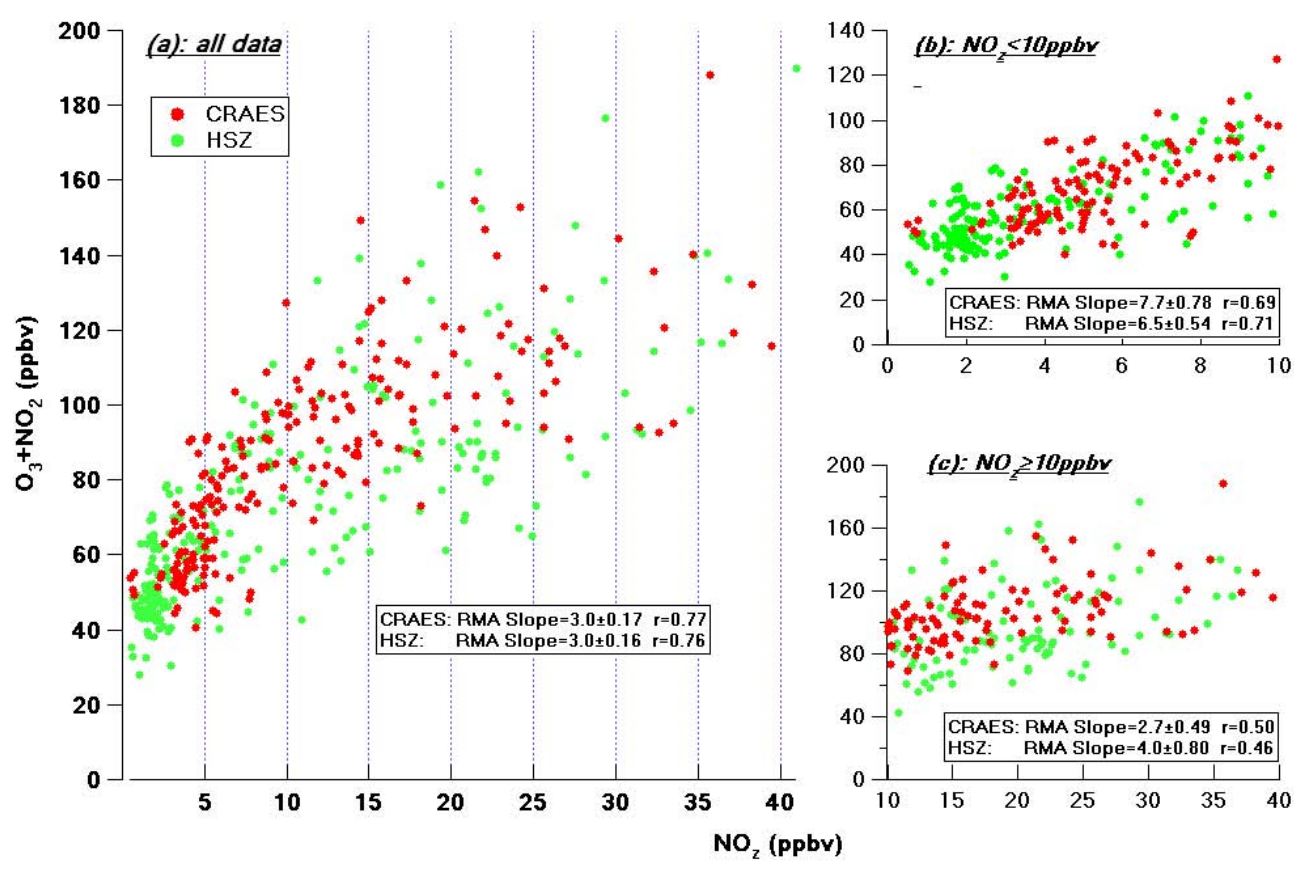

Fig. 8. Scatter plots of $\mathrm{O}_{3}+\mathrm{NO}_{2}$ versus $\mathrm{NO}_{\mathrm{Z}}$ in the afternoon (12:00-17:00) at CRAES (red) and $\mathrm{HSZ}$ (green): (a) all data, (b) $\mathrm{NO} z<10$ ppbv, and (c) $\mathrm{NO}_{\mathrm{z}} \geq 10 \mathrm{ppbv}$.

Chou et al. (2009) observed an average OPE (defined as the regression slope of $\left(\left(\left[\mathrm{O}_{3}\right]+\left[\mathrm{NO}_{2}\right]+\left[\mathrm{NO}_{\mathrm{Z}}\right]\right)\right.$ versus $\left.\left[\mathrm{NO}_{\mathrm{Z}}\right]\right)$ of 6.1 on the Peking University campus in August 2006. The OPE in the present study (using their definition of OPE and for the period of 09:00-13:00 local time) were 3.0 \pm 0.20 and $2.6 \pm 0.17$ at the urban and the mountainous site, respectively, which are much smaller than their value. The data at the HSZ site in 2005 and 2008, however, showed a smaller difference in afternoon $\mathrm{O}_{3}-\mathrm{NO}_{\mathrm{y}}$ slope $(3.7 \pm 0.28$ vs. $2.8 \pm 0.15$ ) (figure not shown). The low values of OPEs in our study indicated a strong VOCs-limited regime in the summer of 2008. The similar OPE at the urban and rural site is also interesting. Previous studies have often shown that as urban plumes advect to rural areas, the loss of $\mathrm{NO}_{\mathrm{y}}$ components such as nitric acid and aerosol nitrate due to wet and dry depositions can lead to increased $\mathrm{O}_{3} / \mathrm{NO}_{\mathrm{z}}$ ratios (Nunnermacker et al., 1998; Wood et al., 2009). The similar values at the two sites in our study can be partially explained by the input of additional ozone precursors between the urban and the mountainous sites. The overall OPE in the present study is comparable to the observed values in Nashville (4.7) (Zaveri et al., 2003), but smaller than that (6-11) observed in Houston (Daum et al., 2004) and in Mexico City (6.2) (Wood et al., 2009).

\subsection{Chemical changes in Beijing and regional plumes}

In this section, we compare a set of chemical species that were measured in 2008 and 2005 at the HSZ site to see whether there were significant changes in the chemical mix of polluted air masses resulting from the control measures that had been gradually implemented in Beijing over the past few years and the special measures that were implemented for the Olympics. The comparison was made for $\mathrm{O}_{3}, \mathrm{CO}$, $\mathrm{NO}_{\mathrm{y}}, \mathrm{SO}_{2}, \mathrm{CO}, 24-\mathrm{h} \mathrm{PM}_{2.5}$ sulfate and nitrate, 24-h $\mathrm{PM}_{2.5}$ mass, and $\mathrm{C}_{2}-\mathrm{C}_{8}$ NMHCs, and only for polluted air masses from the SE-S-SW directions, as determined by the back trajectories. The plume data were collected on 7-8 and 13-19 July in 2005 and on 8-10 and 22-28 July, 4-8 and 24-25 August in 2008. The plume data in 2008 were dominated by the two multi-day episodes that occurred after the full control. Table 1 shows the mean values, standard deviations, and number of samples for the aforementioned species, together with the statistics for temperature, relative humidity, wind speed, and solar radiation measured at the site for the period of plume impact. The results of a $t$-test of the levels of significance in the difference between the means in the two years are also given. The average values of $\mathrm{CO}$ and $\mathrm{NO}_{\mathrm{x}}$ on $8-10$ July in 2008 (before the full control) were a $10-15 \%$ larger compared with the remaining data in 2008 (after the full control), reflecting the effect of the traffic control. But because only two canister samples were collected on July 810 , it was difficult to compare them with the data collected after the full control. Thus the plume data in 2008 were not further divided in Table 1.

Table 1 shows a similar mean temperature and sunlight intensity in the two periods (the mean temperature: $\sim 25^{\circ}$, and mean solar radiation: $\sim 130 \mathrm{~W} / \mathrm{m}^{2}$ ), but the 2008 period was more humid (RH: $87 \%$ versus $75 \%$ ). Although the mean wind speed was larger in 2008 , both were below $1 \mathrm{~m} / \mathrm{s}$, 
Table 1. Comparison of chemical composition and meteorological parameters in plumes measured at a downwind site in north Beijing in 2005 and 2008.

\begin{tabular}{|c|c|c|c|c|c|}
\hline \multirow[t]{2}{*}{ Species/meteorological parameters } & \multicolumn{2}{|l|}{2005} & \multicolumn{2}{|l|}{2008} & \multirow[t]{2}{*}{$P$ (t-test) } \\
\hline & Mean \pm stdev & $\mathrm{n}$ & mean \pm stdev & $\mathrm{n}$ & \\
\hline $\mathrm{O}_{3}$ (ppbv) & $59.4 \pm 30.5$ & 212 & $54.5 \pm 28.4$ & 446 & $<0.05$ \\
\hline $\mathrm{SO}_{2}$ (ppbv) & $7.5 \pm 8.1$ & 211 & $2.7 \pm 2.3$ & 444 & $<0.01$ \\
\hline $\mathrm{CO}(\mathrm{ppbv})$ & $978 \pm 414$ & 211 & $711 \pm 247$ & 444 & $<0.01$ \\
\hline $\mathrm{NO}_{\mathrm{y}}(\mathrm{ppbv})$ & $21.1 \pm 8.7$ & 212 & $20.6 \pm 8.9$ & 442 & 0.47 \\
\hline sulfate $\left(\mu \mathrm{g} / \mathrm{m}^{3}\right)$ & $49.8 \pm 28.0$ & 8 & $48.0 \pm 22.7$ & 19 & 0.87 \\
\hline nitrate $\left(\mu \mathrm{g} / \mathrm{m}^{3}\right)$ & $20.1 \pm 9.0$ & 8 & $14.2 \pm 9.0$ & 17 & 0.15 \\
\hline $\mathrm{PM}_{2.5}\left(\mu \mathrm{g} / \mathrm{m}^{3}\right)$ & $130.3 \pm 51.6$ & 8 & $128.5 \pm 53.3$ & 19 & 0.93 \\
\hline Ethane (pptv) & $3378 \pm 1450$ & 14 & $3236 \pm 1137$ & 55 & 0.74 \\
\hline Ethyne (pptv) & $2773 \pm 1261$ & 14 & $2588 \pm 1064$ & 55 & 0.62 \\
\hline Propane (pptv) & $2060 \pm 1213$ & 14 & $2017 \pm 925$ & 55 & 0.90 \\
\hline Ethene (pptv) & $1736 \pm 1462$ & 14 & $1378 \pm 786$ & 55 & 0.39 \\
\hline n-Butane (pptv) & $1045 \pm 701$ & 14 & $1185 \pm 522$ & 55 & 0.49 \\
\hline Benzene (pptv) & $1077 \pm 514$ & 14 & $1119 \pm 409$ & 55 & 0.78 \\
\hline i-Butane (pptv) & $808 \pm 526$ & 14 & $1101 \pm 436$ & 55 & 0.07 \\
\hline i-Pentane (pptv) & $1059 \pm 692$ & 14 & $1022 \pm 422$ & 55 & 0.85 \\
\hline Toluene (pptv) & $1577 \pm 1184$ & 14 & $776 \pm 443$ & 54 & $<0.05$ \\
\hline Ethylbenzene (pptv) & $271 \pm 206$ & 14 & $196 \pm 110$ & 53 & 0.21 \\
\hline $\mathrm{m}+\mathrm{p}$-Xylene (pptv) & $475 \pm 418$ & 14 & $182 \pm 227$ & 55 & $<0.05$ \\
\hline o-Xylene (pptv) & $173 \pm 137$ & 14 & $52 \pm 68$ & 55 & $<0.01$ \\
\hline 1,2,4-Trimethylbenzene(pptv) & $151 \pm 87$ & 14 & $18 \pm 48$ & 55 & $<0.01$ \\
\hline$T\left({ }^{\circ} \mathrm{C}\right)$ & $25.2 \pm 2.9$ & 215 & $25.4 \pm 2.7$ & 446 & 0.43 \\
\hline $\mathrm{RH}(\%)$ & $74.9 \pm 13.5$ & 215 & $86.6 \pm 11.6$ & 446 & $<0.01$ \\
\hline $\mathrm{WS}(\mathrm{m} / \mathrm{s})$ & $0.68 \pm 0.45$ & 215 & $0.34 \pm 0.26$ & 446 & $<0.01$ \\
\hline Solar radiation $\left(\mathrm{w} / \mathrm{m}^{2}\right)$ & $134.1 \pm 200.8$ & 215 & $130.7 \pm 188.9$ & 446 & 0.80 \\
\hline
\end{tabular}

probably due to the effect of mountainous terrain. The surface wind speeds at HSZ may not be representative of the flow in the planetary boundary layer in the area. Thus in addressing air-mass transport, we used back trajectories and the wind in urban Beijing which showed higher speeds $(2-4 \mathrm{~m} / \mathrm{s})$ on episode days (see Fig. 2).

For the chemical compounds, the average ozone concentration in the plumes decreased by $8.2 \%$ in 2008 compared with 2005 (59.4 ppbv versus $54.5 \mathrm{ppbv}$ ). The maximum 1$\mathrm{h}$ value also decreased to $186 \mathrm{ppbv}$ in 2008 from $199 \mathrm{ppbv}$ in 2005 , and the 90th percentile was $115 \mathrm{ppbv}$ compared to $120 \mathrm{ppbv}$ in 2005 . The mean $\mathrm{SO}_{2}$ value declined by $64 \%$ in 2008 ( 7.5 ppbv compared with $2.7 \mathrm{ppbv}$ ), and the $\mathrm{CO}$ levels decreased by $27 \%$. In contrast, no statistically significant difference was observed for $\mathrm{NO}_{\mathrm{y}}, \mathrm{PM}_{2.5}$ mass, and fine sulfate in 2008 compared with 2005. Of the NMHCs, reactive aromatics such as toluene, xylenes, and 1,2,4-trimethylbenzene decreased by $51 \%, 64 \%$, and $88 \%$, respectively, but the levels of $\mathrm{C}_{2}-\mathrm{C}_{5}$ alkanes, ethyne, and benzene did not change significantly. The decreasing concentrations of ozone, $\mathrm{CO}$, and $\mathrm{SO}_{2}$, in polluted air masses in our study are in agreement with the results of comparing 2007 and 2008 data at a different rural site that is about $42 \mathrm{~km}$ northeast of our site (Wang et al., 2009d). However, the similar $\mathrm{NO}_{\mathrm{y}}$ values in our study in 2008 and 2005 compared with a $21 \%$ decrease in 2007-2008 may indicate an increase in $\mathrm{NO}_{\mathrm{x}}$ emissions between 2005 and 2007. The possible changes in emission during 2005-2008 will be discussed later in this section. The above results indicate that the concentrations of some pollutants at this downwind site have not been reduced, in spite of concerted efforts in Beijing in the last three years before the Olympics and the drastic measures before the Olympics.

Ambient concentrations of the gases and aerosols in the two periods were influenced by the meteorological conditions as well as source emissions. As shown in Table 1, the plumes observed in 2008 were more humid which could lead to faster conversions of $\mathrm{SO}_{2}$ and removal of aerosols and $\mathrm{NO}_{\mathrm{y}}$. This could partially explain the sharp (64\%) reduction in the $\mathrm{SO}_{2}$ level in 2008, but not for the decreases in $\mathrm{CO}$ and VOCs as they are not affected by wet removal and in-cloud processes. The comparable $\mathrm{PM}_{2.5}, \mathrm{NO}_{\mathrm{y}}$, and long lived VOC levels in the two periods imply no reductions in their total emissions in the upwind regions.

We next examine the possible emission changes in the past three years (July 2005-June 2008) and during the special control period (July-August 2008) in both Beijing and the surrounding regions. Atmospheric concentrations of $\mathrm{SO}_{2}$, $\mathrm{CO}, \mathrm{NO}_{\mathrm{x}}$, most of VOCs, and $\mathrm{PM}_{10}$ in urban areas of Beijing 
have decreased in the recent years, indicating reduced emissions of these pollutants in Beijing (UNEP, 2009; Shao et al., 2009). During the special control period, the emissions in Beijing of all the above pollutants have decreased (UNEP, 2009; Wang et al., 2010b). Thus we believe the emissions of $\mathrm{SO}_{2}, \mathrm{CO}, \mathrm{NO}_{\mathrm{x}}, \mathrm{PM}$, most of VOCs in Beijing decreased between the two data-collection periods in 2005 and 2008.

The emission trends in the North China Plain are less clear. National $\mathrm{SO}_{2}$ emission in China reached the peak in 2006 and decreased by $8.9 \%$ during 2005-2008 (NBSC, 20062009). The emission of $\mathrm{NO}_{\mathrm{x}}$, on the other hand, is expected to continue the recent upward trend (Zhang et al., 2009) due to the slow implementation of advanced $\mathrm{NO}_{\mathrm{x}}$ control in coalfired power plants and to a relatively small decrease in $\mathrm{NO}_{\mathrm{x}}$ emissions for new vehicles (Zhang et al., 2009; Zhao et al., 2008). The CO emissions are thought to have stabilized due to a sharp decrease in emissions from new cars (Zhang et al., 2009), while the VOC emissions increased by $29 \%$ during 2001-2006. During the special control period, the emissions of these pollutants are expected to have decreased, although no information on the amount of the reduction is available.

With the consideration of the emission situation, we interpret the observed concentration changes in 2005 and 2008 as follows. The decreases in the concentrations of $\mathrm{SO}_{2}$ (and the total sulfur), CO, reactive aromatics in 2008 are mainly due to the long-term and special control measures implemented in Beijing: $\mathrm{SO}_{2}$ from control of emissions in coalfired power plants, $\mathrm{CO}$ from reduced emissions from vehicles and possibly also from open fires in the North China Plain, toluene, xylenes, and 1,2,4-trimethylbenzene from the control of emissions from vehicles and petrol stations and from solvent and paint use in the run up to and during the Olympics. On the other hand, the insignificant changes in aerosol ( $\mathrm{PM}_{2.5}$ mass and sulfate), $\mathrm{NO}_{\mathrm{y}}$, and longer lived NMHCs during the two periods imply increased emissions from sources outside Beijing and lacking stringent $\mathrm{NO}_{\mathrm{x}}$ control in coal-fired power plants.

The increased regional emission during 2005-2008 inferred from the above analysis and the regional contribution to the very high concentrations of secondary air pollutants after the drastic control measures in the summer of 2008 suggest that more stringent control of the regional emissions will be needed in order to significantly improve the air quality (especially ozone and secondary aerosols) in Beijing and the surrounding regions.

\section{Summary and conclusions}

Atmospheric measurements from this work clearly demonstrate the strong impact of regional sources and meteorology on the variations of secondary pollutants (ozone, fine sulfate and nitrate) in the summer of 2008 in Beijing. The pollution reductions measures for the Beijing Olympics in July and August were successful in reducing atmospheric concentra- tions of primary pollutants such as $\mathrm{NO}_{\mathrm{x}}$ and VOCs. However, high levels of ozone (with hourly values up to $190 \mathrm{ppbv}$ ) and secondary aerosols (with hourly sulfate up to $140 \mu \mathrm{g} / \mathrm{m}^{3}$ ) still occurred at an urban site after the full control took effect, which was strongly associated with the transport of chemically processed air masses from the North China Plain. Regional sources were shown to have significant contribution to the concentrations of ozone and CO (approximately $62 \%$ and $77 \%$, on average, respectively) at the urban site under southerly winds. Much improved air quality on most of the days during the Olympics also had apparent relationship with weather changes (persistent rainfall, lower temperature, and easterly air flow). Further modeling studies are needed to quantify the relative role of the emission reduction and weather changes and the contribution of local versus regional sources to the air quality changes.

By comparing with the data collected in July 2005 at the plume-impacted downwind site, we found similar concentrations of $\mathrm{PM}_{2.5}$ mass, $\mathrm{PM}_{2.5}$ sulfate, total reactive nitrogen and several long lived VOCs. We interpret this as evidence of growing regional emissions during the past several years. On the other hand, the sharp reductions in total $\mathrm{CO}, \mathrm{SO}_{2}$ (and total sulfur), and reactive aromatics suggest the success of the government's efforts in reducing emissions in Beijing by long-term and special measures. The increasing emissions from regional sources could make the pollution control effects in Beijing less effective in mitigating ozone and fine aerosol problems, which are regional in nature. Thus, more stringent controls of regional sources are needed to further improve the air quality in Beijing and the surrounding regions.

Acknowledgements. We thank Jing Wang, Rui Gao, Ravi Pathak, Youping Shou, Linlin Wang, Chao Yuan, Pengju Xu, Zheng $\mathrm{Xu}$, Yangchun Yu, Waishing $\mathrm{Wu}$, Xuehua Zhou, Joe Cheung, and Xuezhong Wang for their contributions to the field work. We thank NOAA Air Resources Laboratory for the provision of the HYSPLIT model. This study was funded by the Research Grants Council of the Hong Kong Special Administrative Region (Project No. PolyU 5294/07E), the National Basic Research Program of China (973 Project No. 2005CB422203), and the Hong Kong Polytechnic University (Project No. 1-BB94).

Edited by: D. Parrish

\section{References}

An, X., Zhu, T., Wang, Z., Li, C., and Wang, Y.: A modeling analysis of a heavy air pollution episode occurred in Beijing, Atmos. Chem. Phys., 7(12), 3103-3114, doi:10.5194/acp-7-3103-2007, 2007.

Cermak, J. and Knutti, R.: Beijing Olympics as an aerosol field experiment, Geophys. Res. Lett., 36, L10806, doi:10.1029/2009GL038572, 2009.

Chen, D. S., Cheng, S. Y., Liu, L., Chen, T., and Guo, X. R.: An integrated MM5-CMAQ modeling approach for assessing trans- 
boundary $\mathrm{PM}_{10}$ contribution to the host city of 2008 Olympic summer games - Beijing, China, Atmos. Environ., 41 (6), 12371250, 2007.

Chou, C. C. K., Tsai, C. Y., Shiu, C. J., Liu, S. C., and Zhu, T.: Measurement of $\mathrm{NO}_{\mathrm{y}}$ during Campaign of Air Quality Research in Beijing 2006 (CAREBeijing-2006): Implications for the ozone production efficiency of $\mathrm{NO}_{\mathrm{x}}, \mathrm{J}$. Geophys. Res.-Atmos., 114, D00G01, doi:10.1029/2008JD010446, 2009.

Colman, J. J., Swanson, A. L., Meinardi, S., Sive, B. C., Blake, D. R., and Rowland, F. S.: Description of the analysis of a wide range of volatile organic compounds in whole air samples collected during PEM-Tropics A and B, Anal. Chem., 73 (15), 3723-3731, 2001.

Daum, P. H., Kleinman, L. I., Springston, S. R., Nunnermacker, L. J., Lee, Y. N., Weinstein-Lloyd, J., Zheng, J., and Berkowitz, C. M.: Origin and properties of plumes of high ozone observed during the Texas 2000 Air Quality Study (TexAQS 2000), J. Geophys. Res.-Atmos., 109, D17306, doi:10.1029/2003JD004311, 2004.

Guo, S., Hu, M., Wang, Z. B., and Zhao, Y. L.: Size-resolved aerosol water-soluble ionic compositions in the summer of Beijing: implication of regional secondary formation, Atmos. Chem. Phys., 10, 947-959, doi:10.5194/acp-10-947-2010, 2010.

Hirsch, R. M. and Gilroy, E. J.: Methods of fitting a straight line to data: examples in water resources, Water Res. Bull., 20(5), 705-711, 1984.

Jia, Y. T., Rahn, K. A., He, K. B., Wen, T. X., and Wang, Y. S.: A novel technique for quantifying the regional component of urban aerosol solely from its sawtooth cycles, Geophys. Res. Lett., 113, D21309, doi:10.1029/2008JD010389, 2008.

Lin, W. L., Xu, X. B., and Zhang, X. C.: Characteristics of gaseous pollutants at Gucheng, a rural site southwest of Beijing, J. Geophys. Res.-Atmos., 114, D00G14, doi:10.1029/2008JD01 0339, 2009.

Liu, J. F., Mu, Y. J., Zhang, Y. J., Zhang, Z. M., Wang, X. K., Liu, Y. J., and Sun, Z. Q.: Atmospheric levels of BTEX compounds during the 2008 Olympic Games in the urban area of Beijing, Sci. Total Environ., 408, 109-116, 2009.

Mijling, B., van der A, R. J., Boersma, K. F., Van Roozendael, M., De Smedt, I., and Kelder, H. M.: Reductions of $\mathrm{NO}_{2}$ detected from space during the 2008 Beijing Olympic Games, Geophys. Res. Lett., 36, L13801, doi:10.1029/2009GL038943, 2009.

NBSC, National Bureau of Statistics of China: China Statistical Yearbook, 2006-2009, China Statistics Press: Beijing, 20062009.

Nunnermacker, L. J., Imre, D., Daum, P. H., Kleinman, L., Lee, Y. N., Lee, J. H., Springston, S. R., Newman, L., Weinstein-Lloyd, J., Luke, W. T., Banta, R., Alvarez, R., Senff, C., Sillman, S., Holdren, M., Keigley, G. W., and Zhou, X.: Charaterization of the Nashville urban plume on July 3 and July 18, 1995, J. Geophys. Res., 103(D21), 28129-28148, 1998.

Pathak, R. K., Wu, W. S, and Wang, T.: Summertime $\mathrm{PM}_{2.5}$ ionic species in four major cities of China: nitrate formation in an ammonia-deficient atmosphere, Atmos. Chem. Phys., 9, 17111722, doi:10.5194/acp-9-1711-2009, 2009.

Shao, M.,Wang, B., Lu, S. H., Liu, S. C., and Chang, C. C.: Trends in summertime non-methane hydrocarbons in Beijing City, 2004-2009, IGACtivity News Letter, 42, 18-25, 2009.

Streets, D. G., Fu, J. S., Jang, C. J., Hao, J. M., He, K. B., Tang,
X.Y., Zhang, Y. H., Wang, Z. F., Li, Z. P., Zhang, Q., Wang, L. T., Wang, B. Y., and Yu, C.: Air quality during the 2008 Beijing Olympic Games, Atmos. Environ., 41(3), 480-492, 2007.

Trainer, M., Parrish, D. D., Buhr, M. P., Norton, R. B., Fehsenfeld, F. C., Anlauf, K. G., Bottenheim, J. W., Tang, Y. Z., Wiebe, H. A., Roberts, J. M., Tanner, R. L., Newman, L., Bowersox, V. C., Meagher, J. F., Olszyna, K. J., Rodgers, M. O., Wang, T., Berresheim, H., Demerjian, K. L., and Roychowdhury, U. K.: Correlation of ozone with $\mathrm{NO}_{\mathrm{y}}$ in photochemically aged air, J. Geophys. Res.-Atmos., 98(D2), 2917-2915, 1993.

UNEP, United Nations Environmental Programme: Independent Environmental Assessment Beijing 2008 Plympic Games, Nairobi, Kenya, 2009, online available at: http://www.unep.org/ pdf/BEIJING_REPORT_COMPLETE.pdf, last access: March 2010 .

Wang, B., Shao, M., Lu, S. H., Yuan, B., Zhao, Y., Wang, M., Zhang, S. Q. and Wu. D.: Variation of ambient non-methane hydrocarbons in Beijing city in summer 2008, Atmos. Chem. Phys., 10, 5911-5923, doi:10.5194/acp-10-5911-2010, 2010a.

Wang, L. T., Hao, J. M., He, K. B., Wang, S. X., Li, J. H., Zhang, Q., Streets, D. G., Fu, J. S., Jang, C. J., Takekawa, H., and Chatani, S.: A modeling study of coarse particulate matter pollution in Beijing: Regional source contributions and control implications for the 2008 Summer Olympics, J. Air \& Waste Manage. Assoc., 58 (8), 1057-1069, 2008.

Wang, M., Zhu, T., Zheng, J., Zhang, R. Y., Zhang, S. Q., Xie, X. X., Han, Y. Q., and Li, Y.: Use of a mobile laboratory to evaluate changes in on-road air pollutants during the Beijing 2008 Summer Olympics, Atmos. Chem. Phys., 9, 8247-8263, doi:10.5194/acp-9-8247-2009, 2009a.

Wang, S. X., Zhao, M., Xing, J., Wu, Y., Zhou, Y., Lei, Y., He, K. B., Fu, L. X., Hao, J. M.: Quantifying the Air Pollutants Emission Reduction during the 2008 Olympic Games in Beijing, Environ. Sci. Technol., 44(7), 2490-2496, 2010b.

Wang, T., Cheung, V. T. F., Anson, M., and Li, Y. S.: Ozone and related gaseous pollutants in the boundary layer of eastern China: Overview of the recent measurements at a rural site, Geophys Res. Lett., 28(12), 2373-2376, 2001.

Wang, T, Ding, A. J., Gao, J., and Wu, W. S.: Strong ozone production in urban plumes from Beijing, China, Geophys. Res. Lett., 33, L21806, doi:10.1029/2006GL027689, 2006.

Wang, W. T., Primbs, T., Tao, S., and Simonich, S. L. M.: Atmospheric Particulate Matter Pollution during the 2008 Beijing Olympics, Environ. Sci. Technol., 43(14), 5314-5320, $2009 \mathrm{~b}$.

Wang, X., Westerdahl, D., Chen, L.C., Wu, Y., Hao, J. M., Pan, X. C., Guo, X. B., and Zhang, K. M.: Evaluating the air quality impacts of the 2008 Beijing Olympic Games: On-road emission factors and black carbon profiles, Atmos. Environ., 43(30), 4535-4543, 2009c.

Wang, Y., Hao, J., McElroy, M. B., Munger, J. W., Ma, H., Chen, D., and Nielsen, C. P.: Ozone air quality during the 2008 Beijing Olympics-effectiveness of emission restrictions, Atmos. Chem. Phys., 9, 5237-5251, doi:10.5194/acp-9-5237-2009, 2009d.

Witte, J. C., Schoeberl, M. R., Douglass, A. R., Gleason, J. F., Krotkov, N. A., Gille, J. C., Pickering, K. E., and Livesey, N.: Satellite observations of changes in air quality during the 2008 Beijing Olympics and Paralympics, Geophys. Res. Lett., 36, L17803, doi:10.1029/2009GL039236, 2009.

Wood, E. C., Herndon, S. C., Onasch, T. B., Kroll, J. H., Cana- 
garatna, M. R., Kolb, C. E., Worsnop, D. R., Neuman, J. A., Seila, R., Zavala, M., and Knighton, W. B.: A case study of ozone production, nitrogen oxides, and the radical budget in Mexico City, Atmos. Chem. Phys., 9, 2499-2517, doi:10.5194/acp-9-2499-2009, 2009.

Wu, W. S. and Wang, T.: On the performance of a semi-continuous $\mathrm{PM}_{2.5}$ sulphate and nitrate instrument under high loadings of particulate and sulphur dioxide, Atmos. Environ., 41(26), 54425451, 2007.

Zaveri, R. A., Berkowitz, C. M., Kleinman, L. I., Springston, S. R., Doskey, P. V., Lonneman, W. A., and Spicer, C. W.: Ozone production efficiency and NOx depletion in an urban plume: Interpretation of field observations and implications for evaluating $\mathrm{O}_{3}-\mathrm{NO}_{\mathrm{x}}$-VOC sensitivity, J. Geophys. Res.-Atmos., 108(D19), 4436, doi:10.1029/2002JD003144, 2003.
Zhang, Q., Streets, D. G., Carmichael, G. R., Huo, H., Kannari, A., Klimont, Z., Park, I. S., Reddy, S., Fu, J. S., Chen, D., Duan, L., Lei, Y., Wang, I. T., and Yao, Z. L.: Asian emissions in 2006 for the NASA INTEX-B mission, Atmos. Chem. Phys., 9 (14), 5131-5153, doi:10.5194/acp-9-5131-2009, 2009.

Zhao, Y., Wang, S. X., Duan, L., Lei, Y., Cao, P. F., and Hao, J. M.: Primary air pollutant emissions of coal-fired power plants in China: Current status and future prediction, Atmos. Environ., 42(36), 8442-8452, 2008. 